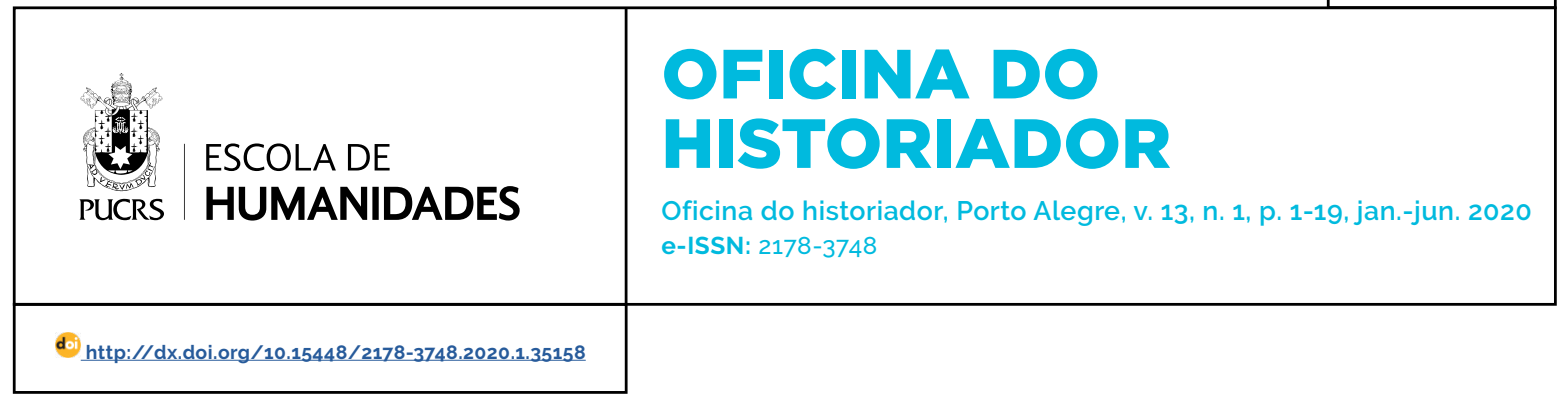

SEÇÃO: ARTIGOS

\title{
O lado "B" de Evandro Teixeira: fotografia e resistência nos Cadernos Culturais do Jornal do Brasil (1963-1979)
}

\author{
The other side (side B) of Evandro Teixeira: photograph and resistance in the Cultural \\ Notebooks of Jornal do Brasil (1963-1979)
}

\section{Reginâmio Bonifácio de Lima ${ }^{1}$ \\ orcid.org/0000-0001-9733-6237} reginamiobonifacio@yahoo.com.br

Recebido em: 31 jul. 2019. Aprovado em: 25 nov. 2019. Publicado em: 14 jun. 2020.

\section{(c) (1)}

Artigo está licenciado sob forma de uma licença Creative Commons Atribuição 4.0 Internacional.
Resumo: este artigo é o primeiro resultado de pesquisa que tem como objeto a análise das críticas e resistências nas fotografias de Evandro Teixeira publicadas na Capa do Caderno de Cultura intitulado "Caderno B" do Jornal do Brasil, durante o regime civil-militar. $O$ foco de análise se concentra mais precisamente no período de participação do fotógrafo no "Caderno de Cultura", que se dá de março de 1963 até a Anistia, em agosto de 1979. Consideramos a expressão dos discursos visuais como enfoque principal e os discursos verbais como aporte de sustentação para analisar as representações jornalisticas. Apresentamos uma breve abordagem sobre a importância do "Caderno B" para a cultura na imprensa jornalistica nacional, seguida de uma contextualização do trabalho do fotógrafo Evandro Teixeira para compreender, ainda que parcialmente, sua trajetória. Apesar de bastante explorada em trabalhos cientíicos, raros são os estudos sobre o fotógrafo dedicados a enfatizar a percepção da inserção de suas fotos nos cadernos culturais; fotografias que extrapolam a cultura e os atos da alta sociedade carioca para denúncias e críticas ao sistema então vigente. As fotos de Evandro Teixeira e as notícias que as acompanham demonstram, por vezes, proximidade com o discurso midiático do drama. O discurso simplificado, muitas vezes de formato afetivo, trazia à luz uma mensagem que pudesse ser facilmente captável pelos leitores. O tempo parece fluir em suas fotos, como se o passado fosse presentificado, ou ainda, como se houvesse uma espiral a confluir ora para frente, ou de outro ângulo, ora para o retorno a um evento que parece ser novamente o que outrora fora, só que diferente - ou ambos ao mesmo tempo, na tessitura de uma rede temporal.

Palavras-chave: Caderno B. Evandro Teixeira. Fotografia. Resistência. Regime civil-militar.

Abstract: this article is the first researching outcome that resulted in the analysis of the criticisms and resistances in the photographs of Evandro Teixeira, published on the Cover of the Culture Booklet entitled Caderno B of the Jornal do Brasil, during the Civil-Military Regime. The analysis focuses more precisely on the photographer's participation in the Culture Book, which runs from March 1963 to Amnesty, in August 1979. We consider the expression of visual discourse as the main focus, and verbal discourse, as input to support, in order to analyze journalistic representations. We present a brief approach on the importance of Caderno $B$ to culture in the national journalistic press, followed by a contextualization of Evandro Teixeira's work to understand, even partially, his trajectory. Although widely explored in scientific work, there are few studies on the photographer dedicated to emphasizing the perception of the insertion of his photos in the Cultural Notebooks; photographs that go beyond the culture and acts of the high society of Rio de Janeiro to denounce and criticize the current system. Evandro Teixeira's photos and accompanying news sometimes demonstrate proximity to the drama's media discourse. His simplified speech, often of an affective format, brought to light a message that readers could easily understand. Time seems to flow in his photos, as if the past were presented, or as if there were a spiral flowing now; or from another angle, sometimes to return to an event that seems to be again what it once was, only different - or both at the same time, in the fabric of a temporal network.

Keywords: Caderno B. Evandro Teixeira. Photograph. Resistance. Civil-military regime. 


\section{Introdução}

O Jornal do Brasil, desde o século XIX, figurou entre os mais importantes do Pais. Porvárias décadas do século XX sua atuação esteve diretamente ligada à política, economia e informação. No periodo que nos propusemos a estudar, com recorte que vai do regime civil-militar brasileiro até a Anistia, em 1979, jornalistas e fotógrafos atuaram no Jornal do Brasil para veicular notícias, denúncias, cultura, informação, dentre outros. Nesse periodo, o fotógrafo Evandro Teixeira passou de recém contratado no Jornal do Brasil para renomado fotógrafo conhecido no Brasil e no exterior. Suas fotos mais que ilustrar matérias ou captar imagens, levavam à reflexão e denunciavam as ações do regime que, assim como o Jornal do Brasil, também teve seu "lado B" pouco explorado.

No Jornalismo, o "Caderno B" era visto como algo absolutamente inovador e rico (SOUZA LIMA, 2006), "o precursor do moderno jornalismo cultural brasileiro" (PIZA, 2003, p. 37). Contudo, pouco se tem de análise sobre esse lado do Jornal do Brasil. De igual modo, o fotógrafo também teve sua atuação muito presente no "Caderno B" do Jornal do Brasil, o que neste artigo chamaremos de "lado B". Por figurar matéria pouco trabalhada e sentir a necessidade de contextualização como aporte de análise, iniciamos com uma breve reflexão sobre o Jornal do Brasil que doravante chamado de JB, os "Cadernos de Cultura" e a parte da atuação de Evandro Teixeira que o deixou conhecido; para, em seguida, analisar o "lado B" do fotógrafo.

O Jornal do Brasil passou por importantes transformações no final da década de 1950, incorporando profissionais de vanguarda em seus quadros e consolidando uma nova forma de apresentar matérias de cultura. Jornalistas, fotógrafos, escritores e artistas plásticos somaram-se ao jornal, oferecendo subsídios de matéria-prima para novos tipos de público e de anunciantes (SOUZA LIMA, 2006, p. 59).

O jornalismo brasileiro se modernizou na década de 1950. Foi gradativamente se afastando de um modelo de "jornalismo europeu", mais próximo do estilo francês (político, literário, panfletário), para se aproximar do "modelo americano de jornalismo" (incorporando as noções de objetividade e de factualidade, padronizando e despersonalizando a escrita) (ABREU, 2002; JÁCOME; VIEIRA, 2019).

O Jornal do Brasil passou por várias modificações e a relação com o público leitor feminino que se estabeleceu desde a primeira coluna de moda escrita em francês, ganhou força nas décadas de 1960 e 1970 nas páginas do "Caderno B".

No tabloide de circulação interna na redação do JB da véspera da inauguração do novo prédio da Avenida Brasil, há um pequeno quadro que informa o perfil do leitor do jornal: homens e mulheres quase se equivalem, pois $52 \%$ do total são do sexo masculino e $48 \%$ do feminino (Jornal do JB, 1971, p. 4)" (SOUZA LIMA, 2015, p. 69).

De acordo com Souza Lima (2015), o Jornal do Brasil teve três mudanças de estilo em seu "Caderno B", todas diretamente relacionadas a mudanças na redação. Souza Lima (2006) afirma que o Caderno $B$ acolheu como membros o editor Masson, Jehovanira Sousa, Carlos Drummond de Andrade, Clarice Lispector, Fernando Sabino, Henfil, Ziraldo, Carlos Leonam e Zózimo Barroso do Amaral, Carlos Castello Branco, João Saldanha, Armando Nogueira e Alceu Amoroso Lima, Marina Colasanti, José Carlos Avelar, Luiz Carlos de Oliveira, além de integrantes do "Caderno 1" e "Caderno C" que contribuiam ativamente com o "Caderno B".

O "Caderno B" foi inovador por inaugurar e institucionalizar esse gênero no Brasil e no mundo, já que não havia essa tradição de caderno cultural diário nos grandes jornais. Com suas ofertas diárias de reportagens, agendas, hábitos sociais, espetáculos e crônicas, influenciou as práticas jornalísticas dos anos de 1960 e seguintes.

Conforme relatam Jácome e Vieira (2019), no "Caderno B" há espaço para cultura, mas também para a política e o autor não perdeu sua identidade, mesmo havendo o esforço de separar e ordenar a realidade em fronteiras estanques e de se situar a cultura em um plano secundário.

O "Caderno B" do Jornal do Brasil tornou-se sinônimo de caderno de cultura, um modelo em que os cadernos diários de cultura brasileiros se ancoraram para traçar "uma combinação de 
arte, literatura, música, teatro e comportamento produzida por jornalistas, escritores e intelectuais" (JÁCOME; VIEIRA, 2009, p. 12).

Com a regulamentação da profissão de jornalista em 1969, as mulheres começam a ocupar espaço no Jornal do Brasil, com influência crescente nos editoriais do "Caderno B".

A atuação de Evandro Teixeira nesses cadernos extrapola os objetivos do "Caderno de Cultura", tendo em vista que leva ao público uma reflexão sobre as demandas da sociedade, tecendo críticas ao contexto em que elas estão inseridas, sendo necessária uma análise dessas fotografias que ora vinham acompanhadas de reportagens produzidas pelo próprio fotógrafo, ora serviam de aporte para textos de outros jornalistas. Suas fotografias levavam não apenas à reflexão, mas também a uma concepção de que a sociedade passava por transformações nem sempre benéficas aos sujeitos presentificados em seu registro fotográfico.

Parece haver uma fluidez do tempo nos cadernos culturais do Jornal do Brasil, ora apontando para frente, ora revisitando temas que parecem emergir do passado. Os cadernos culturais eram capazes de mesclar jornalismo, política, literatura e arte no campo da comunicação em que a sedimentação e a inovação pareciam confluir e conviver como tempos distintos.

Quanto ao tempo, esse tem sido percebido pelos historiadores em dois padrões distintos, conforme Koselleck, (2014, p. 19): primeiro, como cronológico contumaz, rumando sempre ao futuro; e, segundo, como recorrente circular que remete a si mesmo, embora para ele haja insuficiência nos modelos. Para Koselleck "Muitas coisas acontecem ao mesmo tempo, emergindo, em diacronia ou em sincronia, de contextos completamente heterogêneos" (KOSELLECK, 2014, p. 9).

Ao longo das páginas dos cadernos culturais não há o encaixotamento da liberdade de estilo nem o abandono da pirâmide invertida ${ }^{3}$, o lide ${ }^{4}$ e o viés literário conviveram enquanto a política aparecia com frequência em suas páginas e o fotógrafo ganhava ares de autoria em suas fotorreportagens que figuravam como imagens de página cheia, e até o fotógrafo se tornava o autor de textos se debruçando sobre a imagem focalizada.

Evandro Teixeira aprendeu a fotografar com o fotógrafo Teotônio Rocha e, através de um curso de fotografia por correspondência na revista A Cigarra, com o "professor" José Medeiros, já estrela do escrete de fotojornalistas da revista $O$ Cruzeiro. Evandro se aproximou profissionalmente da fotografia ao atuar no Jornal de Jequié, onde trabalhou e aprendeu sobre jornalismo com Walter Lessa, que era fotógrafo do jornal; estagiou no Diário de Notícias, em Salvador, mas foi seguindo os conselhos de seu amigo boêmio Manoel Pinto, mais conhecido como Mapin, que resolveu tentar a sorte como fotojornalista no Rio de Janeiro.

Evandro Teixeira, o premiado fotógrafo, se destacou como um dos maiores fotógrafos brasileiros de todos os tempos, tendo, inclusive seu nome registrado na Enciclopédia Suiça de Fotografia (TEIXEIRA, 2019). Suas atividades fotojornalisticas e suas atividades fotográficas contra os regimes ditatoriais brasileiro e chileno se destacam, além do trabalho intitulado "Canudos, 100 anos". Tudo isso têm sido analisados por diversos pesquisadores. Contudo, há uma face do trabalho de Evandro Teixeira que ainda não foi estudada: sua atuação nos cadernos de cultura do Jornal do Brasil, os chamados "Cadernos B", que começaram a circular no Jornal do Brasil no início da década de 1960 (MAUAD, 1996, p. 14).

Monica Ferrer (2010, p.79) faz um breve relato sobre a trajetória fotográfica e os prêmios obtidos por Evandro Teixeira por causa de sua atuação. Ela afirma:

Evandro Teixeira iniciou sua carreira como fotojornalista no jornal O Diário da Noite, na cidade do Rio de Janeiro. em 1958. Ingressou no Jornal do Brasil em 1963, onde realiza inúmeras coberturas dos mais importantes eventos nacionais e internacionais. Ganhou o Prêmio Sociedade Interamericana de

É o modo de se estruturar um texto de forma que a informação mais importante seja colocada nas primeiras linhas, compondo assim o "lide". 4 Originário da palavra inglesa lead. É o primeiro parágrafo de um texto. Deve ser curto e responder às perguntas básicas do jornalismo: quem? o quê? quando? onde? como? por quê? O ideal é que o lide tenha no máximo cinco linhas. 
Imprensa (Miami) em 1969; o Concurso Internacional Nikon (Japão) em 1975 e em 1981, assim como o Prêmio Especial UNESCO (World Photo Contest) em 1993. Sua obra tem sido exposta em inúmeras ocasiões tanto em mostra pessoais quanto coletivas. Nesse sentido, cabe destacar sua participação na Primeira Mostra de Fotografia Latino-Americana Contemporânea em 1978, no Museu de Arte Moderna da Cidade do México, que o levou posteriormente a exibir suas obras em exposições como Venezia/79, La Fotografia, La Photographie Contemporaine en Amérique Latine, no Centre Georges Pompidou em 1982 e no Museu de Arte Moderna de Nova lorque. De igual modo, a obra de Evandro Teixeira tem sido tema de varias publicações, dentre as quais é valido assinalar: o livro Fotojornalismo (1983), resumo de sua carreira neste gênero, onde aparece o poema dedicado a sua obra, assinado por Carlos Drummond de Andrade. junto aos textos dos escritores Otto Lara Resende e Antonio Callado; o livro Canudos 100 anos (1997) e o documentário de longa-metragem Evandro Teixeira - Instantâneos da Realidade (2004), que acompanha sua trajetória como fotógrafo, que comprovam seu trabalho meritório no contexto nacional; neste sentido, o livro 1968 Destinos, publicado em 2008, desempenha ainda um papel fundamental nesta lista, como veremos posteriormente. Evandro Teixeira continua na ativa até hoje como chefe de fotografia do Jornal do Brasil.

Nosso intuito, neste trabalho, portanto, não é realizar uma análise pautada meramente no efeito estético das fotografias, tampouco referenciálas como aporte para uma análise de contexto, mas, sim, vislumbrar o trabalho do fotógrafo em seu aspecto social, elucidativo e de denúncia da composição social do objeto fotografado.

\section{Materiais e métodos}

A pesquisa foi realizada tendo como apoio metodológico as formulações e a discussão social acerca do fotojornalismo como aporte para compreensão do poder informacional da imagem fotográfica na imprensa escrita brasileira durante o regime civil-militar. Para tanto, partimos da análise do fotojornalismo produzido por Evandro Teixeira nos "Cadernos B" do Jornal do Brasil, tendo em vista seu caráter expositivo, de mediação e de representação entre os acontecimentos e as demandas sociais de seu tempo, recriando narrativas por meio de imagens e fotoexpressões em uma contundente crítica social.

Adotamos uma metodologia do tipo quantitativa e qualitativa, de cunho bibliográfico e documental. Em um primeiro momento, realizamos uma pesquisa bibliográfica pautada na análise de obras de referência sobre o jornalismo cultural e o fotojornalismo brasileiro no período do regime civil-militar, dentre os quais se destacam Souza Lima (2006), Ferrer (2010), Munteal (2005), Gaspari (2002). A partir desses estudos, identificamos algumas características próprias do fotojornalismo, compondo subsidios para discutir o poder informacional e correlacional da imagem fotográfica.

Coletamos dados no próprio site de Evandro Teixeira (2019), identificando as fotografias que o fotógrafo considera como sendo as mais importantes, analisando também os acervos contidos na Enciclopédia Itaú Cultural. Associado a isso, realizamos o levantamento de teses, dissertações e artigos cientíicos que tematizassem a obra de Evandro Teixeira no contexto de regimes ditatoriais, dentre os quais se destacam Armando Fávaro (2009), Paulo Boni (2012), Fabiana Alves (2017). Percebemos, assim, que seu trabalho de registro fotojornalístico das ditaduras militares brasileira e chilena, bem como seus trabalhos de cunho social de revisitação do passado, como por exemplo "Canudos, 100 anos", já foram tema de várias dezenas de análises no Brasil e no exterior. Contudo, nessa vasta produção, há uma parte que aparentemente ainda se encontra ofuscada e necessita de elucidação, sendo essa o objeto do presente trabalho: a atuação de Evandro Teixeira nos "Cadernos B" do Jornal do Brasil.

Quanto à pesquisa quantitativa e documental, realizamos o levantamento de edições do Jornal do Brasil, buscando coletar todas as edições disponiveis dos "Cadernos B", nos Acervos Digitais da Biblioteca Nacional, Hemeroteca da Biblioteca Nacional, no site do próprio Jornal do Brasil e no site da Associação Nacional dos Professores de História (ANPUH). É válido ressaltar que apesar do grande número de edições identificado, todos os acervos digitais consultados encontravam-se 
incompletos. Por isso, não se torna preciso afirmar qual o quantitativo total de capas do Jornal do Brasil em que Evandro Teixeira atuou.

Tendo em vista o grande número de ocorrências ao trabalho fotojornalístico de Evandro Teixeira nos "Cadernos B", elegemos o critério de amostragem para seleção do corpus analisado neste trabalho. Assim, em um primeiro momento, realizamos um levantamento exploratório nas edições do Jornal do Brasil, identificando mais de 750 ocorrências de citações diretas referentes ao fotógrafo Evandro Teixeira, existindo outras centenas de citações indiretas. Desse total, mais de 100 ocorrências encontravam-se em destaque nas capas do jornal, sendo que dessas, foram selecionadas 68 ocorrências em que se observaram críticas diretas e incisivas do fotógrafo como capas dos "Cadernos B".

Para a seleção dessas 68 capas do "Caderno B", utilizamos como critério o fato de apresentarem fotografias que não fossem, na análise de viés fotográfico, meramente ilustrativas, mas aquelas em que as fotografias de Evandro Teixeira fossem a temática central das capas em questão e que essas, para além do que se propõe o caderno cultural, propiciassem críticas e/ou denúncias ao governo ou ao substrato social em que estavam inseridas. Dado o exposto, foram selecionadas 13 capas do "Caderno B" que fulgurassem nessa interposição para análise no trabalho que se segue. Dessa feita, foram escolhidas as páginas de rosto do caderno de cultura que contivessem fotografias produzidas pelo referido fotógrafo para compor o corpus de análise.

Definimos como recorte temporal deste trabalho o período compreendido entre 1963 e 1979, tendo em vista coincidir com o auge da produção fotojornalística de Evandro Teixeira, esboçando desde o momento predecessor à implantação do regime civil-militar até o ano marco do periodo de Anistia geral e irrestrita no Brasil. Ressaltamos que o ano de 1979 não encerra a sua produção do fotojornalista, que ele atuou no Jornal do Brasil até sua aposentadoria, em 2010. Entretanto, definimos como limite do recorte temporal deste trabalho o ano de 1979 como forma de situar o poder informacional da imagem fotográfica no contexto do regime ditatorial.

\section{Resultados e discussão}

Dado o contexto, antes de nos debruçarmos sobre nosso objeto, a saber "o 'lado B' de Evandro Teixeira contido no Caderno B do Jornal do Brasil", vale ressaltar alguns pontos importantes sobre a fotografia e seus teóricos: há a intenção do fotógrafo ou seu financiador (ALVES, 2017), ainda que, para François Soulanges, (2010), o objeto seja infotografável e o que se busca é o fenômeno fotográfico. Assim, para Sousa (1998) o fotojornalismo não substitui o real, podendo representá-lo e mediá-lo, mesmo podendo "jogar com as ideologias, as crenças, os mitos e as expectativas [...] através dos quais uma sociedade vê o mundo" (SOUSA, 1998, p. 85). Para Kossoy (2009), a fotografia possui dois tempos: o efêmero e o perpétuo, o tempo da criação e o tempo da representação. Para ele, "a criação se dá da realidade primeira; já a representação tem seu início a partir da gravação da aparência fotográfica, [...] uma segunda realidade" (KOSSOY, 2009, p. 161), não correspondendo necessariamente à verdade histórica, apenas ao registro (expressivo) da aparência (KOSSOY, 2002, p. 45). André Rouillé (2009) questiona a ideia de fotografia-documento, pois para a fotografia expressão interpreta o acontecimento, mas não o representa.

A trama fotográfica tem várias vertentes e nuances no intra e extraquadro. Uma das características da natureza fotográfica é a polissemia. Para além do que está representado na fotografia, há o leitor, o arcabouço cultural, as interpretações multidisciplinares, o poder evocativo, as escolhas pessoais de para onde olhar, o que escolher, quando e onde enquadrar, enfim, uma variante de conjunturas e escolhas possiveis. Mais que sua construção temporal ou espacial "a fotografia é o resultante do processo de criação/construção do fotógrafo" (KOSSOY, 2002, p. 30). De acordo com Carolina Etcheverry (2016, p. 5),

O quadro e o extraquadro são escolhas do fotógrafo, dependendo de sua orientação ética, moral e cultural, assim como política e ideológica. A fotografia é um recorte de uma realidade que está 


\section{$6 / 19$}

Oficina do historiador, Porto Alegre, v. 13, n. 1, p. 1-19, jan.-jun. 2020 | e-35158

à frente do fotógrafo, e é esse recorte que é determinado por escolhas.

As fotografias são portadoras de historicidade própria, quando estudadas em sua materialidade. Cada imagem traz em si a marca do momento do registro, do clic fotográfico, e das escolhas feitas pelo fotógrafo. Os fotógrafos, nesse sentido, atuam como agentes sociais, na medida em que fazem a transposição de sua realidade social para a imagem fotográfica.

Embora pareça óbvio, há a necessidade de se pensar os estratos temporais da história do fotojornalismo e do próprio jornalismo que tiveram suas bordas criadas para ordenar, mas que também apartam as temporalidades múltiplas que podem trazer à tona o passado presentificado no olhar de quem escolheu estar integrado à dimensão lúdica da cultura - tão demonizada pela massificação e pela mercantilização da cultura. Os cadernos culturais passam por uma crítica ideológica que confunde diversão com evasão, que condena o ócio contemplativo, que tange para o vício os momentos que seriam de reflexão e de entusiasmo e de relaxamento em contexto social.

É no caderno de cultura que os principais diários brasileiros registram o surgimento e o sucessivo fortalecimento da produção cotidiana (GADINI, 2009, p. 26).

O "Caderno B" abriu-se para o mundo. Seu conteúdo, que antes era restrito à divulgação de entretenimento e lazer, passou a ser definido pela ênfase dada às áreas de cultura, lazer e informações complementares de coberturas de grandes acontecimentos cotidianos. Souza Lima (2006) afirma que o "Caderno B" era projetado matutinamente em função dos newspeg, que é um "gancho" que atualiza uma informação de outro acontecimento, assunto ou problemática já veiculados, renovando o potencial da notícia; cumprindo, assim, a função jornalística do feature que são matérias cujo valor jornalístico não necessariamente está ligado ao dia de sua ocorrência, podendo ser publicado de acordo com o espaço disponível. Vimos claramente a atuação de Evandro Teixeira nessas duas funções jornalisticas presentes nas capas do "Caderno B".

Imagem 1 - Citações de Evandro Teixeira no JB, acervo da Hemeroteca Digital da Biblioteca Nacional

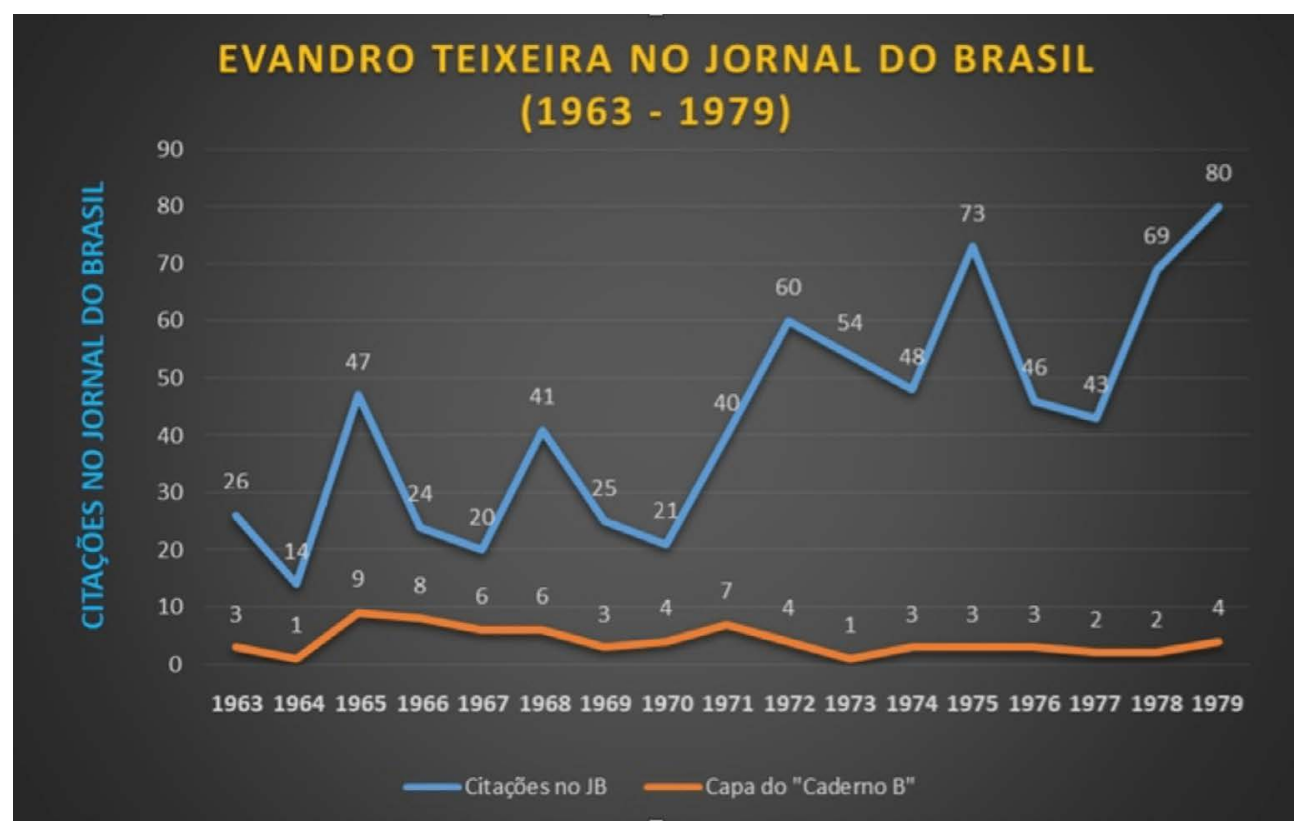

Fonte: elaborada pelo autor com base nos dados da Hemeroteca Digital da Biblioteca Nacional. ${ }^{5}$

5 Disponivel em: http://bndigital.bn.gov.br/hemeroteca-digital/. Acesso em: 6 jun. 2019. 
Conforme se pode constatar na Imagem 1 , das mais de 700 citações de Evandro Teixeira no Jornal do Brasil, pelo menos 68 se deram na capa do "Caderno B", dedicado à cultura e ao entretenimento. Contudo, não foi somente isso o que se viu nas fotos de Teixeira. O fotógrafo criticou os governantes, o descaso com os menos favorecidos, a criminalização de ações cotidianas e a mordomia dos altos cargos. A rua foi tida, quase sempre, como passarela para artistas e transeuntes pintarem suas vivências e o fluxo de suas vidas como arte em uma passarela de cultura e de resistência cotidiana.

Nas quase sete dezenas de capas do "Caderno B" há dois aspectos estampados: o ser e a cultura - não necessariamente nessa mesma ordem. Em quase um quarto delas há a produção de discurso fotográfico crítico-reflexivo sobre formas heterodoxas de se ver cultura.

Para este artigo, fizemos a separação de cinco grupos de fotos que foram capa do "Caderno B" do Jornal do Brasil. Nosso intuito aqui é mais o de demonstrar a existência desse material fotográfico e a consequente existência disso que escolhemos chamar de "lado B" do fotógrafo Evandro Teixeira, do que, necessariamente, analisar cada uma delas - o que demandaria muito tempo e algumas dezenas de páginas fugindo ao ideal de concisão de como elemento básico de um artigo.

Grande parte das capas do "Caderno B" cumpriam rigorosamente os trâmites do que se espera de um caderno de cultura, dentro dos parâmetros supracitados com base nos autores anteriormente mencionados. Contudo, uma quantia significante de capas e matérias tendem a acentuar "o ponto fora da curva", sendo pouco mais de uma dúzia as capas que dão notícias de críticas e reflexões incisivas contra o contexto do sistema em que estavam inseridas. Primeiramente, foi dada ênfase ao "O Estado em desencanto", como forma de demonstrar fotograficamente a visão do jornal que outrora apoiara a ação militar contra o Governo eleito e que, já não pretendia apoiar a continuação do regime; em segundo lugar, o "Despreparo em
Prever", onde a ênfase é dada na megalomania de construções gigantescas enquanto ações simples de infraestrutura e de manutenção cotidiana são relegadas ao ocaso; em terceiro lugar, "A política cotidiana intermitente", em que o Brasil participa de ações, se relaciona com outras nações, percebe pontos de tensão, mas não consegue avançar, nem se faz notar por suas ações que até começam, mas logo cessam para somente depois de acionadas recomeçar e novamente cessar; em quarto lugar, "A interferência direta do Estado em benefício próprio e contra os mais fracos", esse conjunto de fotos mostra o Estado presente, massacrando o cidadão em nome de um beneficio que se volta apenas ao Estado; em quinto lugar, "A resistência nas ruas contra a invisibilidade e o apagamento", os excluídos resistem mesmo que tenham sido impelidos para fora do convívio cotidiano reciproco.

\section{Estado em desencanto}

Duas fotos marcam o início da atuação de Evandro Teixeira: "Sinal dos Tempos", do "Caderno A", e, "Tomada do Forte de Copacabana", do "Caderno B", icones de seu "lado A", de seu fotojornalismo de manchetes e páginas principais. Essas fotos dão inicio a outras dezenas que se prefigurariam em reflexões e premiações.

No dia 23 de maio de 1966, em um evento em homenagem à atuação brasileira no centenário da Batalha de Tuiuti - Guerra do Paraguai -, o fotógrafo enfoca três baionetas em posição vertical, destacando duas libélulas voando alinhadas na ponta das primeiras armas; destacando no "Chapéu" (que serve para caracterizar o assunto ou o personagem da notícia) o "Sinal dos Tempos", que mais tarde perfiguraria como liberdade acima das armas.

Nesse instante único, há o flagrante de uma imagem inusitada e bela que se multiplica por seu caráter polissêmico. Em seu contexto, há o fundo em uma composição de ramos e folhas das árvores que vão perdendo sua nitidez pelo foco que se centra no vazio preenchido pelas armas que se perfilam.

O que seria a representação do ápice de 
repressão, violência e ameaça à integridade, seja pelo potencial de fogo dos tiros, impacto contaminador dos projéteis de chumbo, ou perfurocortar das baionetas pontiagudas, não é reverenciada pela liberdade que se apresenta delicada, mas palpável, em vislumbres de afronta à ação militante. A mensagem de resistência às formas que se faz engrenar, de liberdade acima das ameaças e, de leveza em meio à altivez, estimula no espectador uma evocação à liberdade, uma ideia simbólica de resistência possivel.

\section{Imagem 2 - Sinal dos Tempos}

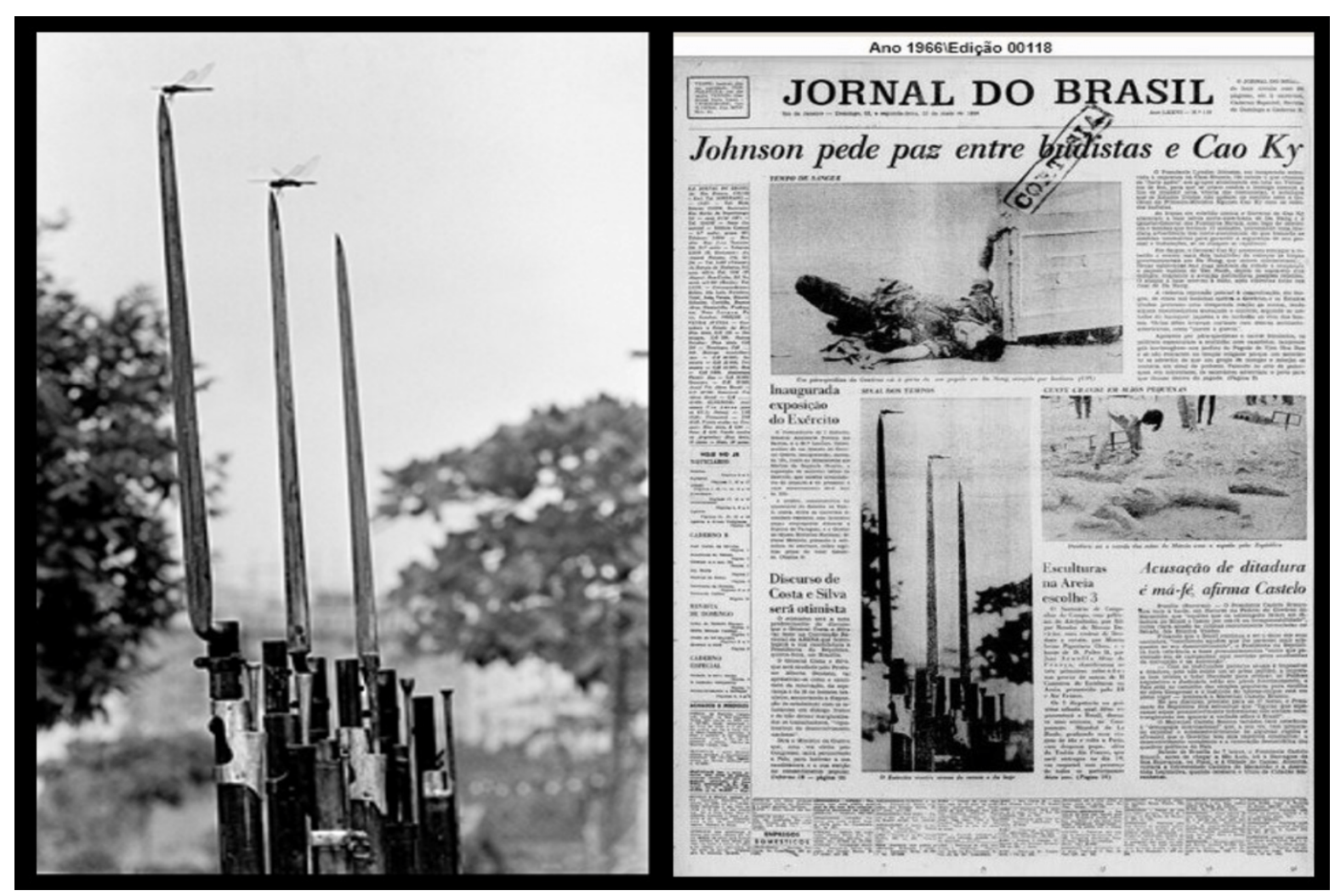

Fonte: montagem realizada pelo autor com capa do Jornal do Brasil, 23 maio 1966. ${ }^{6}$

Fabiana Alves (2017) afirma que essa foi uma das primeiras manifestações dos profissionais do fotojornalismo brasileiro. Evandro Teixeira foi chamado a dar explicações sobre o porquê de a capa do Jornal do Brasil estampar a imagem de "besourinhos" e não das autoridades como o General Artur da Costa e Silva - candidato da Arena à Presidência. Quando chegou ao Palácio das Laranjeiras, Teixeira acabou ficando uma noite detido no prédio como uma forma de castigo.

Além dessa, várias foram as atuações do fotógrafo que o fizeram, por vezes correr da polícia, por outras, se esconder das autoridades. Ele, que sempre afirmou não ser comunista, deixou claro em seu trabalho a necessidade de refletir sobre o sistema e a sociedade.

Como Evandro Teixeira, que já era conhecido fotógrafo do Jornal do Brasil, se consagrou no fotojornalismo brasileiro? Alfredo Ribeiro (2019) afirma que o fotógrafo fazia parte de um grupo de vizinhos que jogava vôlei e se encontrava na boemia nas calçadas do canto oposto ao Leme, em Copacabana - grupo eclético formado por um médico, advogado, um piloto da Varig. um oficial da Marinha, e outros, "mas foi Leno, capitão do Exército já desencantado com a caserna, o parceiro que tirou Evandro da cama na madrugada daquele $1^{\circ}$ de abril com um passe

6 Disponivel em: http://memoria.bn.br/docreader/030015_08/84526. Acesso em: 6 jun. 2019. 
preciso para uma boa reportagem: "Estourou o golpe, estão tomando o forte de Copacabana.
Vou pra lá, topa vir comigo? Pega sua câmera!" (RIBEIRO, 2019, p. 1).

Imagem 3 - A queda em abril (Tomada do Forte de Copacabana)

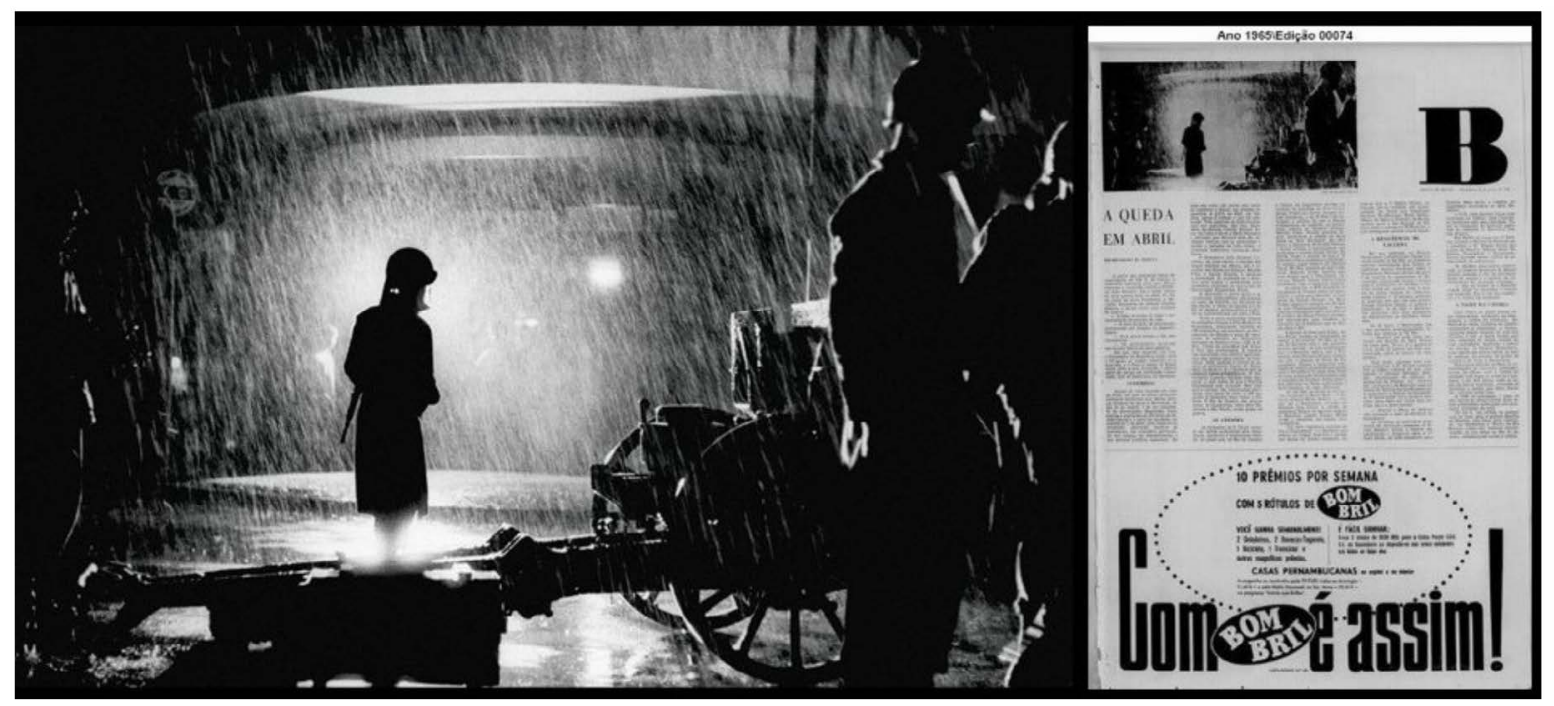

Fonte: montagem realizada pelo autor com base em Jornal do Brasil. Caderno B, de 31 de março de $1965 .^{7}$

A percepção, ainda que intuitiva, de que no meio da escuridão da noite, na entrada do Forte de Copacabana, em meio à composição de chuva, soldados em prontidão, entrada estreita quase sufocante, o aguardar algo ou alguém que fulguraria no horizonte, para além das luzes que refratam o olhar, prefigurando de terceiro plano e avançando rumo à instalação, aos corpos descritos por sua silhueta, ora iluminados, ora sombreados, no momento de risco que parece uma cena de filme de guerra, o fotógrafo aciona o click que parece apontar para o passado, presentificando-o e, como que em perspectiva, projetando em tessitura uma visão do futuro sombrio vindouro. $\mathrm{O}$ elemento detonador chega no veículo aguardado, e, em meio ao contexto em que está se inserindo, arremete ao protagonismo de opressão de um futuro incerto que estava por vir, entre "fardas e forças" que não permitiam ver a composição da luz, antes faziam contrapontos só permitindo ver o que se lhes era fora de contorno, em dias que se tornariam sombrios, a verter lágrimas apreensivos pelo despertar do "monstro que emerge da lagoa".

\section{Despreparo em prever}

A cidade está em constante movimento. Movimento esse que está no traslado de turistas que antes era feito nas carruagens cognominadas "vitórias". A matéria intitulada "Um príncipe luta em Petrópolis para evitar a derrota das vitórias" retrata a luta dos Cocheiros de Petrópolis que persistiam em permanecer fazendo os passeios com os turistas pela charmosa cidade e que gradativamente estavam sendo substituidos pelos trenzinhos turísticos. Não havia no Governo a intenção de extinguir esses serviços, ao mesmo tempo, não se percebe ações de manutenção dos mesmos.

Próximo dali, na Capital fluminense, com as águas de março, as ruas da cidade transbordavam, levando os carros que de seguros e confortáveis, são arrastados pelas correntezas até que as águas baixem e seus donos, em meio à lama, venham resgatá-los. 


\section{$10 / 19$}

Oficina do historiador, Porto Alegre, v. 13, n. 1, p. 1-19, jan.-jun. 2020 | e-35158

Imagem 4 - A derrota das vitórias. A louca deriva dos carros. Pontemania

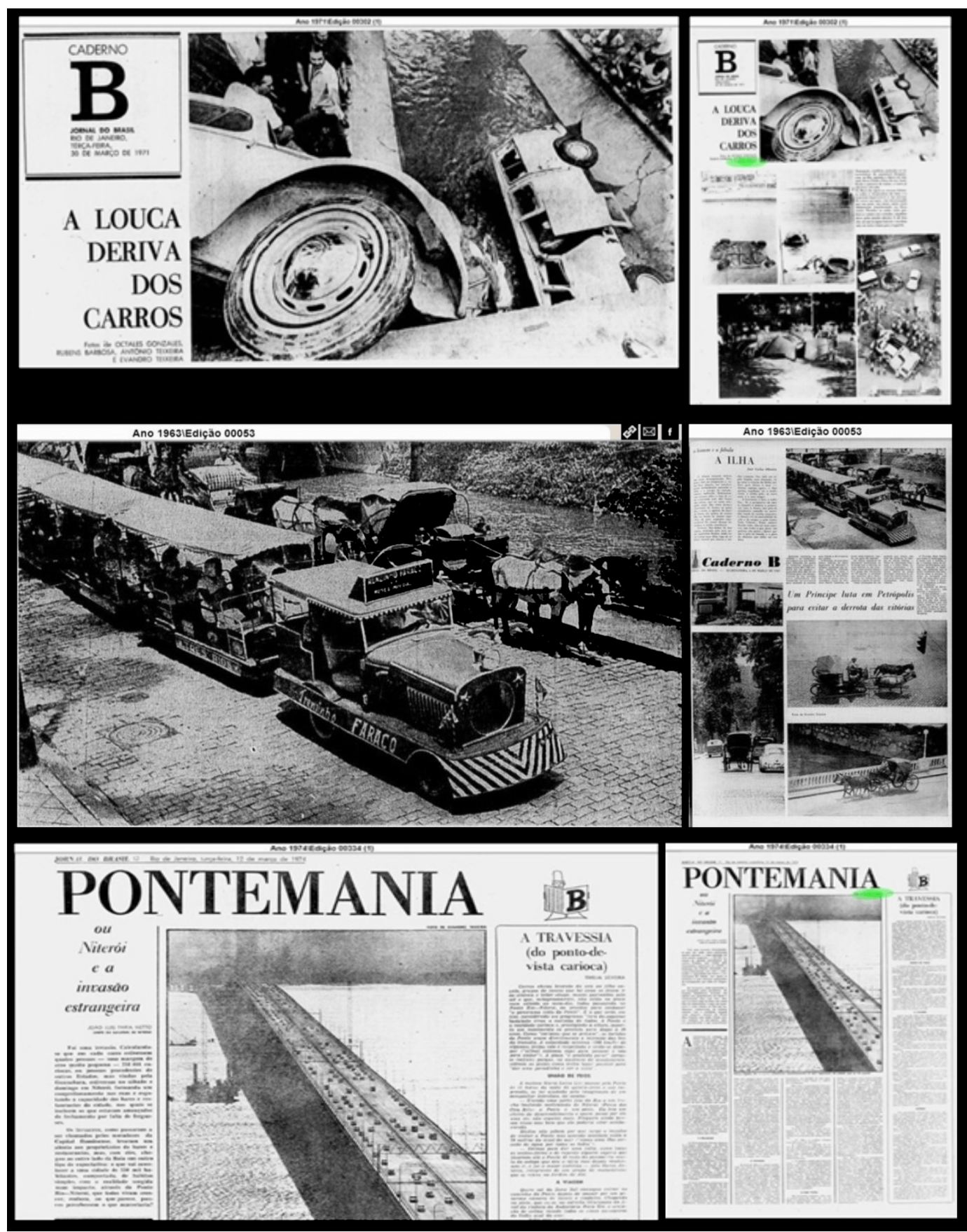

Fonte: montagens realizadas pelo autor com base em Jornal do Brasil. Caderno B, de 6/3/1963; de 30/3/1971; de $12 / 3 / 1974 .^{8}$ 
A ênfase dada à megalomania de construções gigantescas denotava no cenário internacional o Rio de Janeiro como a "Cidade Maravilhosa", contudo, com a chegada das águas, vem à tona, juntamente com elas, a percepção de que ações simples de infraestrutura e manutenção cotidiana foram relegadas ao ocaso.

Com a inauguração da Ponte Rio-Niterói ficou claro que não houve previsão em acomodações para a imensa leva de turistas que se deslocariam para o outro lado da Baía de Guanabara. Dessa forma, a pacata cidade de Niterói, com pouco mais de 350 mil habitantes, foi tomada pelos "invasores" que lotaram seus bares, restaurantes, hotéis, praças, quiosques, pontos turísticos e de serviços após a inauguração da ponte Rio-Niterói. O mesmo governo que implementou a ponte não investiu na cidade, que receberia grande fluxo de veículos e pessoas a congestioná-la com mais de 250 mil visitantes por dia nos fins de semana.

As três fotorreportagens dão conta de movimentos: movimento de resistência para sobreviver dos cocheiros de Petrópolis; movimento das águas que sempre sobem em março, demonstrando a falta de prevenção na limpeza de esgotos e consciência ambiental que ocasiona, a cada grande chuva, prejuizos muitos pela deriva dos carros; e, movimento de moradores para tentar acomodar a grande leva de turistas indo da cidade do Rio de Janeiro para a cidade de Niterói. Pensou-se na ponte como ligação, mas não na cidade como receptora desse fluxo de pessoas.

\section{A Política cotidiana intermitente}

O fazer política parece estar às avessas nesse grupo de imagens que se segue. "Notícia com ironia" e "Pobre Menina rica" são duas notícias que se entrelaçam: de um lado, o Governador do Rio de Janeiro Badger Silveira e seu filho recebem dos cosmonautas Pavel e Adrian (tidos como espiões russos) um broche representando a nave espacial Vostok II em troca da cortesia de terem recebido duas pedras de quartzos ialinos; do outro lado, o primeiro musical do teatro brasileiro, "Pobre menina rica", é anunciado - inspirado em Nara Leão, escrito pelo poeta Vinícius de Morais e o Menestrel Carlos Lira. As mensagens se entrelaçam pelo fato de o Governador não saber o que fazer com a quebra do protocolo por parte de seu filho e de seus visitantes, enquanto a menina-mulher é tratada "poeticamente" como "Menina Cabeça de Vento sem um pensamento". "Você não sabe o que amor. Não sabe, eu sei...". Parece que o Governador e a menina estão sendo ensinados por seus coadjuvantes.

No registro fotográfico da Organização dos Estados Americanos (OEA), em novembro de 1965. o Ministro Luiz Viana Filho, chefe da delegação brasileira e demais representantes da entidade internacional, parecem estar exauridos após um dia de debate. $O$ fotógrafo mostrou em uma página cheia os vários representantes das nações bocejando, cabisbaixos e até cochilando, em um plenário que seria para debater ações para a OEA.

Na matéria "O irresistivel esporte do furto" o contexto dá conta de que os roubos são muitos e acabam por ocupar a polícia e as páginas dos jornais. O fotógrafo chama atenção para o ato do furto que, muitas vezes, passa despercebido pela grande midia e, na maioria das vezes, nem é registrado na polícia. As imagens mostram como pessoas utilizavam de artificios para burlar a segurança dos estabelecimentos comerciais e praticar pequenos furtos. Objetos como guarda-chuvas, bolsas grandes, sacolas e livros eram utilizados para cometer essas ações. O furto parecia ter se tornado um esporte e as pessoas passavam por obstáculos, inventando novas formas de alcançar seus objetivos - apropriar-se do que era alheio.

Novamente entrava em cena a ineficiência dos sistemas de segurança, fazendo com que os lojistas investissem em vigilância privada e ficassem mais atentos às possiveis ações dos indivíduos que tentassem usurpar os produtos das lojas. 
Imagem 5 - Notícia com ironia. O exausto mundo novo. O irresistível esporte do furto

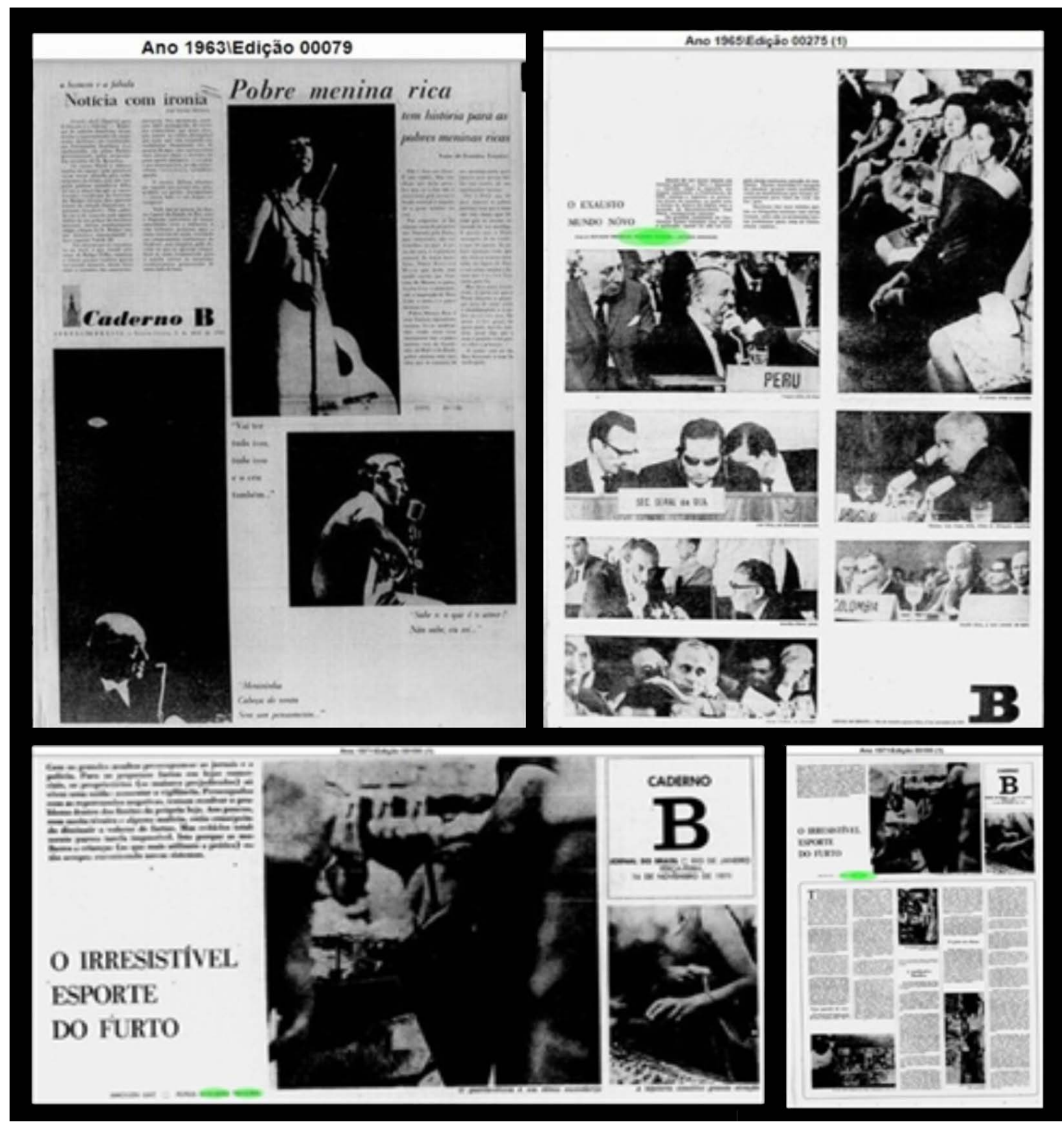

Fonte: Montagens do autor com base em Jornal do Brasil. Caderno B. de 5/4/1963; de 24/11/1965; de 16/11/1971.9

Nos três casos descritos percebe-se que havia uma ação política, mas essa não era eficaz, seja pelas gafes em eventos, pela sonolência e exaustão em momentos de decisão ou, ainda, pela incapacidade de repelir ações delituosas de pequeno potencial ofensivo à segurança, mas de grande potencial de prejuizo econômico.

\section{A interferência direta do Estado em}

benefício próprio e contra os mais fracos

As três fotorreportagens que se seguem dão conta da ação do Estado interferindo diretamente no contexto social para beneficiar a si mesmo. 
Imagem 6 - O ato de observar. O nosso de cada dia. Tenho vergonha da mordomia dos altos cargos

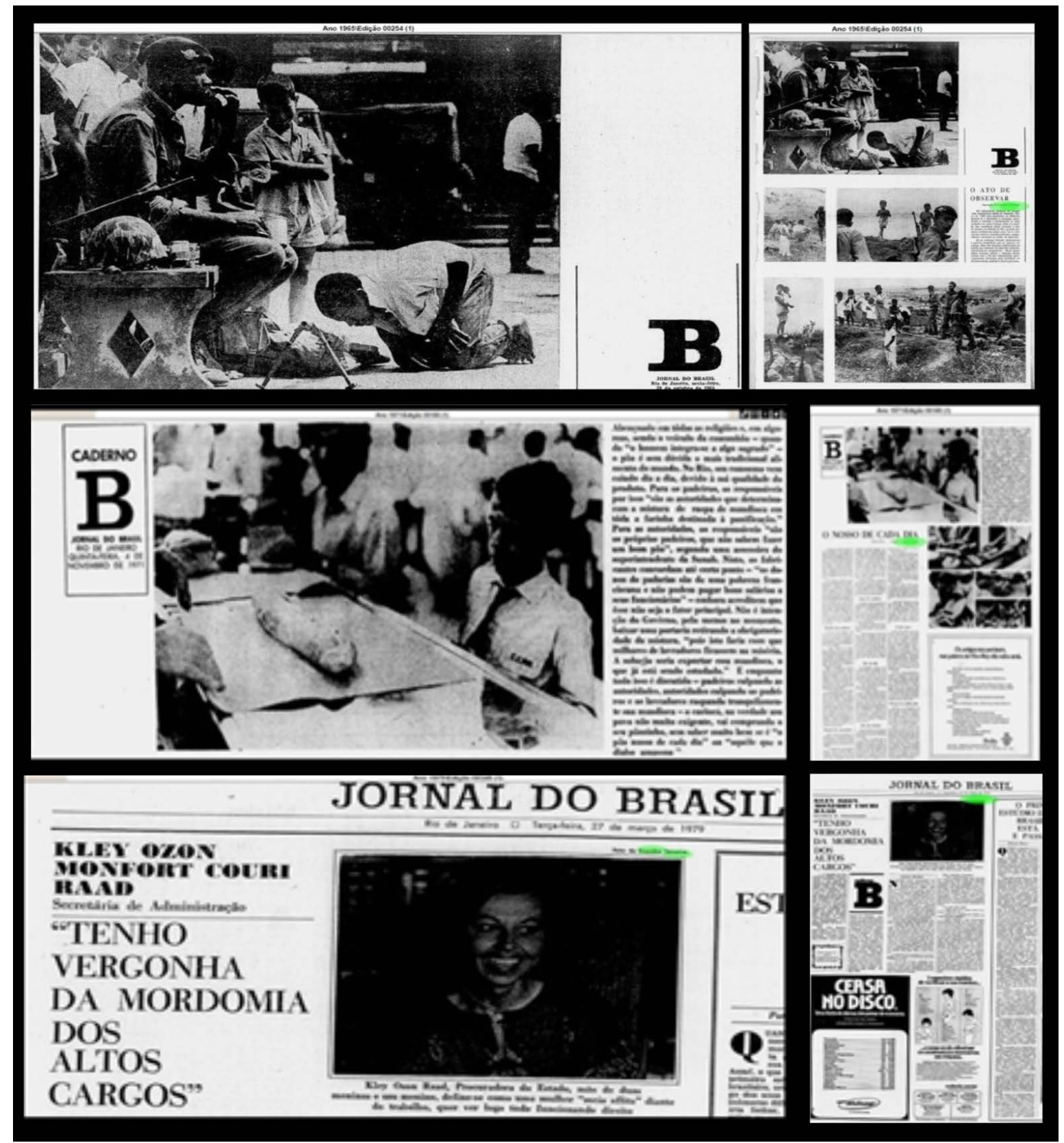

Fonte: Montagens realizadas pelo autor com base em Jornal do Brasil. Caderno B. de 29/10/1965; de 04/11/1971. ${ }^{10}$

Em "O ato de observar", o olhar fotográfico remonta as pessoas simples do Resende observando as tropas de paraquedistas do Exército que foram até a localidade para acabar com a "ocupação comunista".

Nas fotografias reportadas, não fica claro a existência de "comunistas", não há prisões, nem confrontos, apenas a ocupação maciça sob os olhares curiosos dos moradores. A guerra imaginária, como é retratada, não foi percebida pelas crianças pobres da comunidade que gastaram seu tempo admiradas com as armas. $O$ fotógrafo indica a condição das crianças "muito tristes" e do dia ao reportar a "chuva que caiu". O 
Estado ali era estranho, ameaçador e ocupante de um espaço que não estava vazio.

Ao reportar "O nosso de cada dia", fica clara a ação impositiva do Governo em obrigar os padeiros a incluírem na receita do pãozinho uma quantidade de raspa de mandioca, mesmo sabendo que esse ato iria alterar o sabor e diminuir a qualidade do pão. A matéria deixa claro que o Governo não sabia o que fazer com a produção de mandioca, nem com os trabalhadores que dela sobreviviam e transferindo esse problema para o setor da panificação. Como a portaria que institui a inclusão da mandioca na confecção dos pãezinhos, a matéria conclui: "o carioca, na verdade, um povo não muito exigente, vai comprando seu pãozinho, sem saber bem se é 'o pão nosso de cada dia' ou 'o pão que o diabo amassou'".

A terceira desse grupo de capas do Caderno intitulada "Tenho vergonha da mordomia dos altos cargos" dá conta das palavras proferidas pela Procuradora do Estado do Rio de Janeiro que havia sido recém empossada Secretária Municipal de Administração Kley Ozon Monfort Couri Raad Ela faz críticas às mordomias que os detentores de altos cargos têm na administração pública. Em sua análise, o Estado se aproveitava do ato de administrar para tirar vantagens para aqueles que ocupavam os cargos, enquanto o povo não tem suas necessidades atendidas.

Nos três casos, há a explícita crítica à ingerência do Estado que, com a desculpa de regular a liberdade, a cerceia ocupando os espaços de direito do povo. Espaço físico público, espaço alimentício privado e espaço econômico social são desabonados por ações que enfatizam a interferência estatal em benefício próprio.

\section{$5 \mathrm{~A}$ resistência nas ruas contra a invisibilidade e o apagamento}

No conjunto de fotografias que se segue, temos o ambiente modificado antropicamente pelo ser humano e o paradoxo que se reflete no contexto em que as imagens estão inseridas.
Em contraste ao título "A morada na infância", um menino de cinco anos de idade, a quem o fotógrafo chama de Marinho, vive em uma ponte, tendo dois cachorros por família. O garoto vive no entre-lugar, na ligação entre duas margens. O foco não é se ele tem pais presentes, mas na vivência dele, que se dá entre veículos, fumaça, desconhecidos e cachorros, em um profundo vazio de estar só em meio à cidade. Para ele, não há praças, nem parques, muito menos playgrounds ou lugares de lazer. A realidade nua e crua se contrasta com o glamour de um casal, aparentemente de classe média, que, da orla, apoia-se na firmeza de um canhão, protegido ao chão por uma coluneta de encosta e, ao alto por coqueiros refrescantes, enquanto ostentam subscritos pelo slogan "feitos um para o outro", mencionando o ato de prazer ao fumar, icone de "tradição e bom gosto". Abaixo do garoto há a propaganda e o lançamento de um livro sobre "As primeiras famílias do Rio de Janeiro", em uma clara propositura de que algumas familias importavam, outras nem tanto.

Na segunda foto, cuja legenda é "A pelada, essa grave paixão", trata do ato simples de crianças jogarem bola nas ruas do Rio de Janeiro, que havia se tornado uma contravenção, de acordo com um delegado de Polícia. O Juizado da Infância havia se pronunciado afirmando que iria criar uma comissão para estudar o caso. O interessante na notícia é que há a proibição do uso das ruas para o jogo, que é considerado "paixão nacional", contudo, não há nenhuma ação do Estado como aporte para que essas crianças possam jogar. 0 Estado retira o que fora comum e corriqueiro, o tangencia como sendo contraventor e, ainda, pune aqueles que permanecessem a fazer o que se repetia há gerações, a saber: jogar bola na rua. O foco não está no fato de determinar se há ou não risco, mas na punibilidade de um ato antes corriqueiro, frente à inexistência de oferta de outra localidade para a prática esportiva. Por fim, o fotógrafo conclui informando que "ainda não há notícias da construção de campinhos para as crianças sairem das ruas e jogarem bola neles". 
Imagem 7 - A morada da infância. A pelada, essa grave paixão. A arte que cresce nas ruas
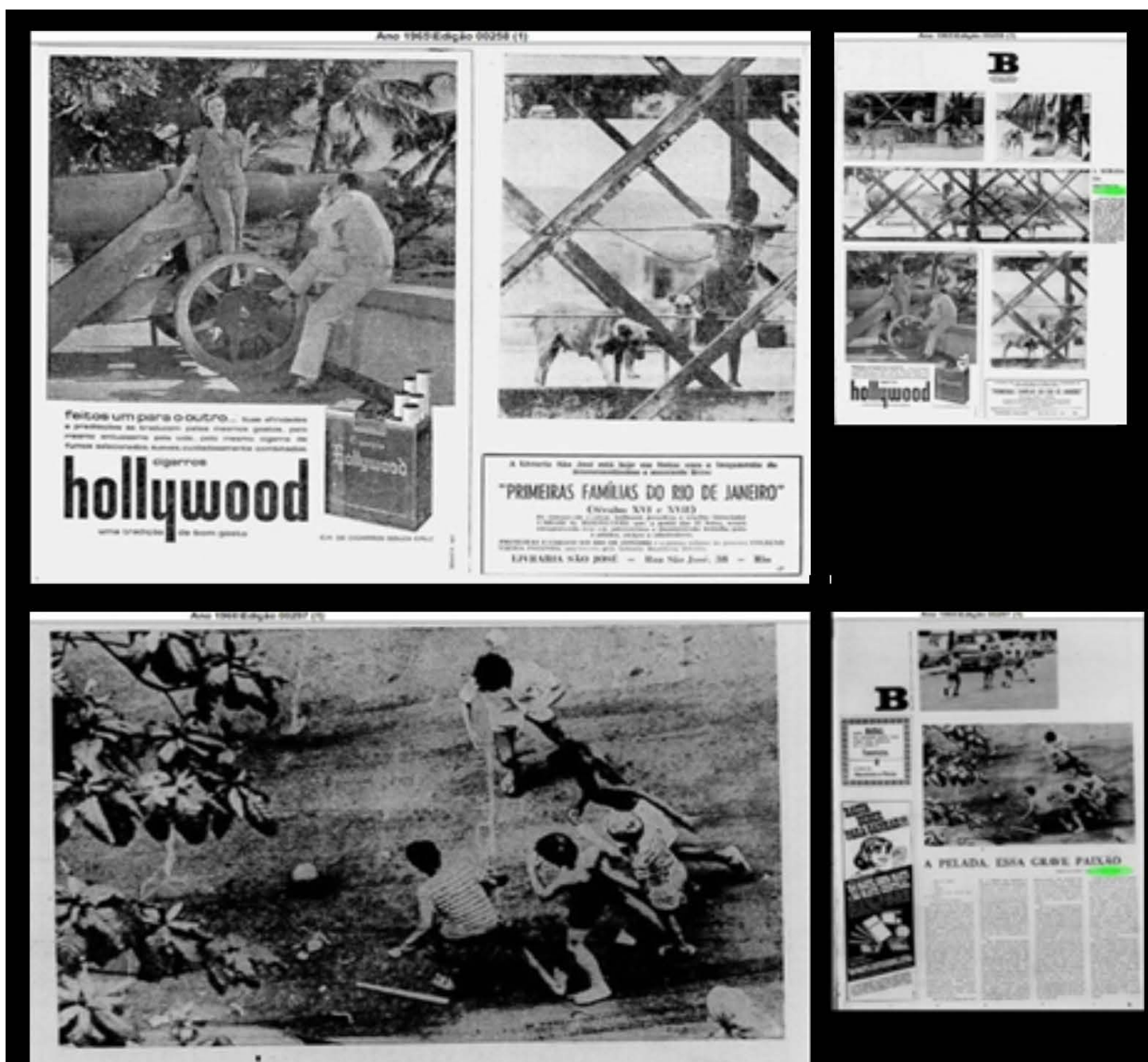

A PELADA, ESSA GRAVE PAIXÃo

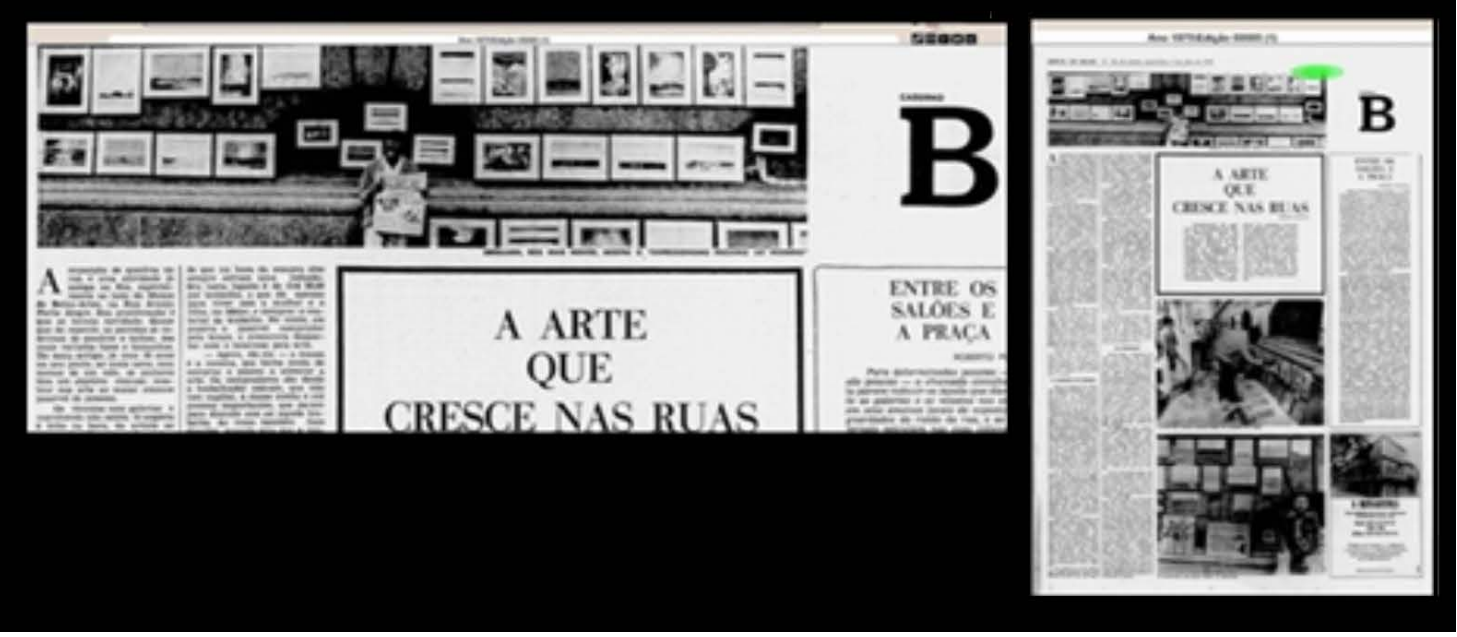

Fonte: Montagens realizadas pelo autor com base em Jornal do Brasil. Caderno B. de 6/11/1965; 18/12/1966; 2/7/1975. ${ }^{11}$ 
A matéria seguinte, "A arte que cresce nas ruas", critica o circuito de arte por ser fechado a um pequeno grupo de artistas e informa que existe uma ampla maioria de artistas que não é contemplada com o circuito de museus, galerias e mostras públicas em ambientes reservados e que, por isso, utiliza as ruas, praças, paredes como seu ateliê, e os transeuntes como seu público-alvo. $\mathrm{Na}$ matéria provocativa são feitos questionamentos sobre o que é arte, indagando o porquê de uma arte se dizer melhor que a outra.

No texto da matéria que acompanha a fotografia, o artista Roberto Pontual, que estava expondo seus trabalhos na rua, afirma:

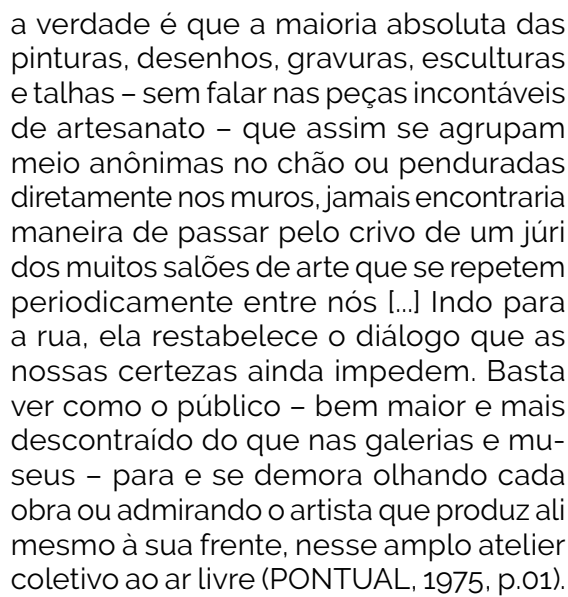

Para o autor, o fundamento e a perspectiva não são de confundir uma e outra forma de arte, de dizer que uma ou outra é melhor, mas de ter a compreensão sobre as reais razões que separam tão amplamente essas duas parcelas - tanto a arte que se diz erudita quanto a popular devem ser valorizadas e aceitas pelo público, os circuitos, o júri, as taxas e o contexto de expressão artística é que precisam ser repensados.

Vale ressaltar que as fotografias não são objetos neutros. Elas passam por processos de escolha, desde a ótica do fotógrafo, a escolha da câmera, o tipo de filme, o ponto em que está inserido, e uma sucessão de escolhas das quais o assunto da foto é o resultado. Entender claramente uma fotografia não é uma questão simples. Para Victor Burgin:

As fotografias são textos inscritos em termos do que poderiamos chamar de "discurso fotográfico", mas este discurso, como qualquer outro, origina discursos que vão mais além. O "texto fotográfico", como qualquer outro, é um ambiente de intertextualidade complexa [...] em uma conjuntura histórica e cultural determinada (BURGIN, 2006, p. 67).

De igual modo, esse "lado B" do fotógrafo nos faz refletir sobre as entrevistas que já concedeu sobre suas obras, dentre elas, um destaque específico: quando perguntado sobre sua atuação no periodo do regime civil-militar, o fotógrafo respondeu com uma frase singela, mas de grande profundidade: "Minha arma foi minha câmera fotográfica. Com ela eu subi em palanques, entrei em palácios e em presídios, corri, apanhei, mas eu precisava registrar aquilo tudo, precisava deixar documentos para a história" (TEIXEIRA, 2012, p. 244).

Ao refletir sobre as imagens fotográficas suprapostas fica claro que o autor teve a intenção do click, embora não esteja nítida sua intencionalidade quanto aos processos de temporalidade, sociabilidade ou semiótica. É certo que outras análises e aprofundamentos nos estudos das imagens são necessários e virão em tempo oportuno.

\section{Considerações finais}

O Jornal do Brasil que apoiara o regime civilmilitar, contrapondo-se repulsivamente aos rumos que parecia tomar o governo Goulart, mas também que necessitava sopesar os dilemas de sobreviver em um regime autoritário, tomou posição ambígua. Sua atuação estava cindida entre o amor à ordem e a devoção à liberdade, o que, por vezes, levou o veículo a fazer concessões ao autoritarismo. Nesse contexto, é perceptivel, embora latente, o dilema do "Caderno B" em apresentar a sociedade diante do regime civil-militar. A sensibilidade do fotógrafo torna tangivel o cotidiano que oscila entre a dependência de continuar atuando profissionalmente e o desejo de autonomia.

Através do discurso visual, o fotojornalismo incorporou estratégias que alavancaram a eficácia de sua mensagem, buscando no imaginário social novas construções que servissem de influência e referência para sua elaboração.

Ao fazer uma análise crítico-comparativa de 
algumas fotos contidas no "Caderno B" foi possivel a percepção da conjuntura histórica em que essas se desenvolvem. Evandro Teixeira demonstra valores-notícia em suas fotos, os quais podem ser nominados alguns dentre os sistematizados por Souza: o ineditismo das imagens e/ou situações; a temporalidade simbólica expressa nos acontecimentos que poderiam ter repercussão de longo prazo; a violência das cenas; a captura do "momento decisivo" da ação em movimento; a dramatização do olhar para perceber o contexto; a novidade que se apresenta; o conflito evidente, dentre outros (SOUSA, 2000).

Ao refletir sobre a história por trás da imagem, percebemos o momento único e não repetivel do acontecimento que relaciona o ocorrido, a visão do fotógrafo e a nossa própria percepção. Avaliar e sopesar esses momentos com a valoração do discurso comunicado através da imagem fotográfica projeta a tessitura do emaranhado de relações presentes que se somam e redimensionam seu papel como fotojornalismo, arte, memória e vertentes de tempo

A ligação com a realidade é um elemento fundamental que transborda nas fotografias analisadas. A relevância dada ao efêmero e ao cotidiano transpõem a experiência criativa e o papel de narração para se apresentar como arte que fala de momentos únicos e comunicativos que elucubram nossa própria experiência na interação com a imagem.

É possivel encontrar nas fotografias, o estudo da enunciação, através de vestígios que permitem a recomposição da formação do discurso fotografado. Esses indícios possibilitam priorizar que recursos foram acionados quando da produção de sentido dessas imagens.

Mesmo que fixada em um tempo/espaço, a fotografia de Evandro Teixeira cria um discurso, atuando o fotógrafo como um intérprete da história que produz sentidos que se inserem em um conjunto de escolhas possiveis.

As fotografias analisadas cumpriram os ritos do processo jornalístico para sua primeira publicação, além da qualidade estética. Fica claro que o fotógrafo conhecia os mecanismos internos do jornal para o qual trabalhava, uma vez que seus trabalhos "encheram" as páginas de cerca de capas de 68 edições do "Caderno B" - afora as cerca de 2.000 contribuições para outras partes do jornal, incluindo a capa.

Resistindo à censura durante a ditadura militar, as fotografias de Evandro Teixeira se inseriram no imaginário coletivo como imagens-referência. Sua capacidade de narrativa imagética reverberou no leitores a possibilidade de eles se identificarem com os personagens das situações fotografadas.

Evandro Teixeira atuou por várias décadas no "Caderno B" do Jornal do Brasil. Ao longo desse percurso, observamos que quanto mais se destacava no fotojornalismo, ocupando as primeira páginas do jornal, menos atuava nos cadernos culturais.

A forma sutil com a qual o fotógrafo estabeleceu o relacionamento com a imagem captada por sua câmera infere ao click a percepção de momento grafada com uma linguagem capaz de atravessar os filtros da censura e suportar o discurso politizado. Assim, fotografias e autor parecem transbordar a ideia de "veículos da verdade". Suas mensagens parecem se dirigir à consciência da sociedade convidando à reflexão sobre a vida cotidiana que se apresenta em cena.

\section{Referências}

ABREU, Alzira Alves. A modernização da imprensa: 1970-2000. Rio de Janeiro: Jorge Zahar, 2002.

ALVES, Fabiana Aline. Fotojornalismo à força: ângulos e planos dos agentes políticos no regime militar brasileiro (1966-1975). Tese (Doutorado em História) Faculdade de Ciências e Letras, UNESP, 2017.

BONI, Paulo César. Entrevista: Evandro Teixeira. Discursos fotográficos, Londrina, v. 8, n.12, p. 217-252, jan./ jun. 2012. https://doi.org/10.5433/1984-7939.2012v8n12p217

BONI, Paulo César. O discurso fotográfico: a intencionalidade de comunicação no fotojornalismo. Tese (Doutorado em Ciências da Comunicação) - ECA/ Universidade de São Paulo, São Paulo, 2000.

BURGIN, Victor. Olhando fotografias. In: FERREIRA, Glória; COTRIM, Cecilia (org.). Escritos de artistas: anos 60/70. 2. ed. Rio de Janeiro: Jorge Zahar Editor, 2006. p. $389-400$ 
ETCHEVERRY, Carolina Martins. Fotografias da Ditadura CivilMilitar brasileira em livros didáticos de história. Revista Tempo e Argumento, Florianópolis, v. 8, n. 17, p. 292-310, jan./abr. 2016. Acesso em: 24 maio 2019. https://doi.org/10.5965/2175180308172016292

FÁVARO, Armando. O Fotojornalismo durante o Regime Militar: imagens de Evandro Teixeira. Dissertação (Mestrado em Comunicação e Semiótica) - Pontifícia Universidade Católica de São Paulo - PUCSP, São Paulo, 2009.

FERRER, Monica Villares. Arte fotográfica e liberdade de expressão: um diálogo entre o Brasil e Cuba (19601990). Dissertação (Mestrado em Arte) - Instituto de Filosofia e Ciências Humanas, Universidade Estadual de Campinas, Campinas, 2010.

GADINI, Sérgio Luiz. Interesses cruzados: a produção da cultura no jornalismo brasileiro. São Paulo: Paulus, 2009.

GASPARI, Elio. A ditadura envergonhada. São Paulo: Companhia das Letras, 2002.

JÁCOME, Phellipy; VIEIRA, Itala Maduell. O lado B do jornalismo: como os cadernos culturais entram na história. Contracampo, Niterói, v. 37, n. 03, p. 1-17, dez. 2018/mar. 2019. https://doi.org/10.22409/contracampo.v37i3.19456

KOSELLECK, Reinhart. Estratos do tempo. Estudos sobre História. Rio de Janeiro: Contraponto, 2014.

KOSSOY, Boris. Fotografia e história. São Paulo: Ateliê Editorial, 2009

KOSSOY, Boris. Realidades e ficções na trama fotográfica. 3. ed. São Paulo: Ateliê Editorial, 2002.

MAUAD, Isabel Cristina. Da origem dos suplementos literários e cadernos culturais: origens no Brasil e trajetória no Rio de Janeiro. Rio de Janeiro, 1996. Dissertação (Mestrado em Comunicação e Cultura) - Escola de Comunicação, Universidade Federal do Rio de Janeiro, Rio de Janeiro, 1996.

MUNTEAL, Oswaldo; GRANDI, Larissa. A imprensa na história do Brasil: fotojornalismo no século XX. Rio de Janeiro: PUC-Rio/Desiderata, 2005.

PIZA, Daniel. Jornalismo Cultural. São Paulo: Contexto, 2003.

RIBEIRO, Alfredo. Instante Zero do Golpe. Disponivel em https://ims.com.br/2017/11/28/instante-zero-golpe/. Acesso em: 04 jun. 2019.

ROUILLÉ, André. A fotografia: entre documento e arte contemporânea. Trad. Constancia Egrejas. São Paulo: Editora Senac São Paulo, 2009

SOULAGES, François. Estética da fotografia: perda e permanência. Tradução de Iraci D. Poleti e Regina Salgado Campos. São Paulo: Editora Senac São Paulo, 2010.

SOUSA, J. B. As notícias e os seus efeitos: as teorias do jornalismo e dos efeitos sociais dos media jornalisticos. Coimbra: Edições Minerva, 2000.
SOUSA, Jorge Pedro. Fotojornalismo performativo: o serviço de fotonotícia da Agência Lusa de Informação. Porto: Universidade Fernando Pessoa, 1998.

SOUZA LIMA, Patricia Ferreira de. Caderno B do Jornal do Brasil: trajetória do segundo caderno na imprensa brasileira (1960-85). Tese (Doutorado em História Social) - Instituto de Filosofia e Ciências Sociais da Universidade Federal do Rio de Janeiro - UFRJ, Rio de Janeiro, 2006

SOUZA LIMA. Patricia Ferreira de. "Meninas do B" no caderno de cultura do Jornal do Brasil da abertura política (1974-1985). Revista Transversos, Rio de Janeiro, v. 03, n. 03, p. 59-76, out.-mar. 2014/2015. Disponivel em: www.transversos.com.br. ISSN 2179-7528.

TEIXEIRA, Evandro. A fotografia a serviço da luta contra a ditadura militar no Brasil. Discursos Fotográficos, Londrina, v.8, n.12, p. 217-252, jan./jun. 2012. https:// doi.org/10.5433/1984-7939.2012v8n12p217

TEIXEIRA, Evandro. A morada na infância. Jornal do Brasil, Rio de Janeiro, 06 de novembro de 1965. Disponivel em http://memoria.bn.br/docreader/030015_08/76164. Acesso em: 06 jun. 2019.

TEIXEIRA, Evandro. Canudos 100 anos. 2. ed. Rio de Janeiro: Textual, 1997.

TEIXEIRA, Evandro. Evandro Teixeira: fotojornalismo. Textos de Carlos Drummond de Andrade, Marcos Sá Correa, Antonio Callado e Otto Lara Rezende. 2. ed. Rio de Janeiro: JB, 1982.

TEIXEIRA, Evandro. In: ENCICLOPÉDIA Itaú Cultural de Arte e Cultura Brasileiras. Verbete da Enciclopédia. São Paulo: Itaú Cultural, 2019. Disponivel em: http:// enciclopedia.itaucultural.org.br/pessoa7623/evandro-teixeira. Acesso em: 06 jun. 2019. ISBN: 978-857979-060-7

TEIXEIRA, Evandro. O ato de observar. Jornal do Brasil, Rio de Janeiro, 29 de outubro de 1965. Disponivel em http://memoria.bn.br/DocReader/030015_08/75880. Acesso em: 06 jun. 2019.

TEIXEIRA, Evandro. O fotógrafo arretado que o Brasil e o mundo aprenderam a admirar. Entrevista concedida a Célia Chaim em outubro de 2009. Jornalista e Cia. Disponivel em: http://www.jornalistasecia.com. br/especial.htm. Acesso em: 30 maio 2019.

TEIXEIRA, Evandro. Vidas secas: 70 anos, Graciliano Ramos. Rio de Janeiro: Record, 2008

TEIXEIRA, Evandro; CASTRO, Marcos de. A pelada, essa grave paixão. Jornal do Brasil, Rio de Janeiro: 18 e 19 de dezembro de 1966. Disponivel em http://memoria.bn.br/DocReader/030015_08/93618. Acesso em: 06 jun. 2019.

TEIXEIRA, Evandro; DANÚSIA, Bárbara. Tenho vergonha da mordomia dos altos cargos. Jornal do Brasil, Rio de Janeiro, 27 de março de 1979. Disponivel em: http://memoria.bn.br/DocReader/030015_09/196497. Acesso em: 06 jun. 2019 
TEIXEIRA, Evandro; MACKSEN, Luiz. O irresistivel esporte do futuro. Jornal do Brasil, Rio de Janeiro, 16 de novembro de 1971. Disponivel em http://memoria. bn.br/DocReader/030015_09/44363. Acesso em: 06 jun. 2019.

TEIXEIRA, Evandro; MALTA, Dacio. O nosso de cada dia. Jornal do Brasil, Rio de Janeiro, 04 de novembro de 1961. Disponivel em http://memoria.bn.br/DocReader/030015_09/43518. Acesso em: 06 jun. 2019.

TEIXEIRA, Evandro; NETTO, João Luis Faria. Pontemania. Jornal do Brasil, Rio de Janeiro, 12 de março de 1974. Disponivel em http://memoria.bn.br/DocReader/030015_09/101501. Acesso em: 06 jun. 2019.

TEIXEIRA, Evandro; OLIVEIRA, José Carlos. O homem e a fábula: notícia com ironia. Jornal do Brasil, Rio de Janeiro, 05 de abril de 1963. Disponivel em http://memoria.bn.br/DocReader/030015_08/38353. Acesso em: 06 jun. 2019

TEIXEIRA, Evandro; OLIVEIRA, José Carlos. Um príncipe luta em Petrópolis para evitar a derrota das Vitórias. Jornal do Brasil, Rio de Janeiro, 6 de maio de 1963. Disponivel em http://memoria.bn.br/docreader/030015_08/37281. Acesso em: 06 jun. 2019

TEIXEIRA, Evandro; PONTUAL, Roberto. A arte que cresce nas ruas. Jornal do Brasil, Rio de Janeiro, 02 de julho de 1975. Disponivel em http://memoria.bn.br/ DocReader/030015_09/124751. Acesso em: 06 jun. 2019.

\section{Reginâmio Bonifácio de Lima}

Doutorando pela Pontifícia Universidade Católica do Rio Grande do Sul - PUCRS. Membro da Academia Acreana de Letras. Professor de História na Universidade Federal do Acre.

\section{Endereço para correspondência}

Reginâmio Bonifácio de Lima

Pontificia Universidade Católica do Rio Grande do Sul. Av. Ipiranga, 6.681, Prédio 8. Partenon, 97010-082. Porto Alegre, RS, Brasil 